Reprinted with permission from: Applied Animal Behaviour Science. 1996, 50(2): 161-176.

Published and copyrighted by: (C) 1996 Elsevier Science B.V. All rights reserved. PII S0168-1591(96)01066-0. Single copies of this article can be downloaded and printed for the reader's personal research and study. http://www.elsevier.com/locate/applanim and http://www.ScienceDirect.com

\title{
Effect of previous experience on sheep grazing leafy spurge
}

\author{
B. E. OLSON*, R. T. WALLANDER, V. M. THOMAS, and R. W. KOTT \\ *Department of Animal and Range Sciences, Montana State University - Bozeman, Bozeman, MT 59717, USA.
}

\begin{abstract}
:
Herbivores develop preferences for certain plant species in several ways. One way is to learn from role models, another is through postingestive feedback. In this study we determined (1) whether yearling sheep exposed to leafy spurge (Euphorbia esula L.) as lambs graze it more readily than yearlings that were not exposed to it as lambs, and (2) whether this difference, if present, persists through the grazing season. On a leafy spurgeinfested, Idaho fescue (Festuca idahoensis Elmer) range site, we compared the grazing behavior of naive groups of Targhee yearlings with grazing behavior of experienced groups for 3 years. Using focal animals, we assessed diet selectivity by counting bites and by determining time spent grazing different forage types. During the grazing season, nutritive value (crude protein, neutral detergent fiber, in vitro dry matter digestibility) of leafy spurge was always higher than nutritive value of Idaho fescue. Experienced yearlings spent more than four times as much time grazing leafy spurge in early summer compared with naive yearlings (averaged across 1992 and 1993, experienced 13.6\% vs. naive 2.9\%), whereas in mid- (39\% vs. 31\%) and late summer (37\% vs. 38\%) both groups spent similar amounts of time grazing leafy spurge. Neither group readily grazed the plant in early summer. Experienced yearlings had higher bite rates of leafy spurge than naive yearlings during the early summer sampling periods in 1992 and 1993 (averaged across 1992 and 1993, 15.9 vs. 5.0 bites $\min ^{-1}$ ) but their bite rates were similar by mid-summer ( 22.7 vs. 20.6 bites $\min ^{-1}$ ). In 1994, we observed their grazing behavior every 5 days for 35 days. Initially, naive yearlings spent less time grazing leafy spurge than experienced yearlings, but were spending similar amounts of time grazing
\end{abstract}

\footnotetext{
${ }^{1}$ Accepted 29 February 1996.
} 